\title{
Healthcare Worker's Mental Health During the Epidemic Peak of COVID-19 [Letter]
}

This article was published in the following Dove Press journal:

Psychology Research and Behavior Management

\author{
Heru Santoso Wahito \\ Nugroho (D) \\ Joel Rey Ugsang Acob ${ }^{2}$ \\ Wiwin Martiningsih ${ }^{3}$ \\ 'Poltekkes Kemenkes Surabaya, Surabaya, \\ Indonesia; ${ }^{2}$ Faculty of Nursing, Visayas \\ State University, Baybay, Philippines; \\ ${ }^{3}$ Nursing Department, Poltekkes \\ Kemenkes Malang, Malang, Indonesia
}

Correspondence: Wiwin Martiningsih Nursing Department, Poltekkes

Kemenkes Malang, Jl. Ijen 77 C, Malang, Indonesia

Email martini227।@gmail.com

\section{Dear editor}

We have read the article "Healthcare Worker's Mental Health and Their Associated Predictors During the Epidemic Peak of COVID-19". Based on the results, the researchers concluded that healthcare worker's stress, anxiety and depression are influenced by social-support, working time, discrimination and workplace violence; and not influenced by age, gender, working at designated hospital, medical equipment, patient-physician relations and household transmission-related fears. ${ }^{1}$

Is it true that seven variables have no effect on stress, anxiety and depression? Could these variables have an indirect effect on stress, anxiety and depression? Which statistical analysis can be used to analyze this indirecteffect?

In this study, the authors used a logistic-regression test, a method used to analyze the effects of independent variables on the dependent variable simultaneously. Thus, it has been assumed that all independent variables have a directeffect on stress, anxiety and depression.

It is unlikely that all variables have a direct-effect on stress, anxiety and depression. There are several variables which have an indirect-effect through intervening variables. For example, age is related to working at designated hospitals, working at designated hospitals has an effect on discrimination experience, then discrimination experience has an effect on stress, anxiety and depression. Referring to other cases, ${ }^{2,3}$ we propose a framework involving independent, intervening and dependent variables (Figure 1), which the researchers can check and modify.

Based on Figure 1, the researchers can carry out further analysis to test the significance of each effect pathway, so that, the direct-effect, indirect-effect and total-effect will be obtained. In this case, the appropriate method is pathanalysis. ${ }^{2-4}$ In this study, the researchers used data with nominal scale, so one of the suitable statistical software is Smart-PLS. ${ }^{4}$

We recommend that researchers undertake a further analysis, in order to obtain more complete information on the effects of the eleven variables on stress, anxiety and depression.

\section{Disclosure}

The authors report no conflicts of interest for this communication. 


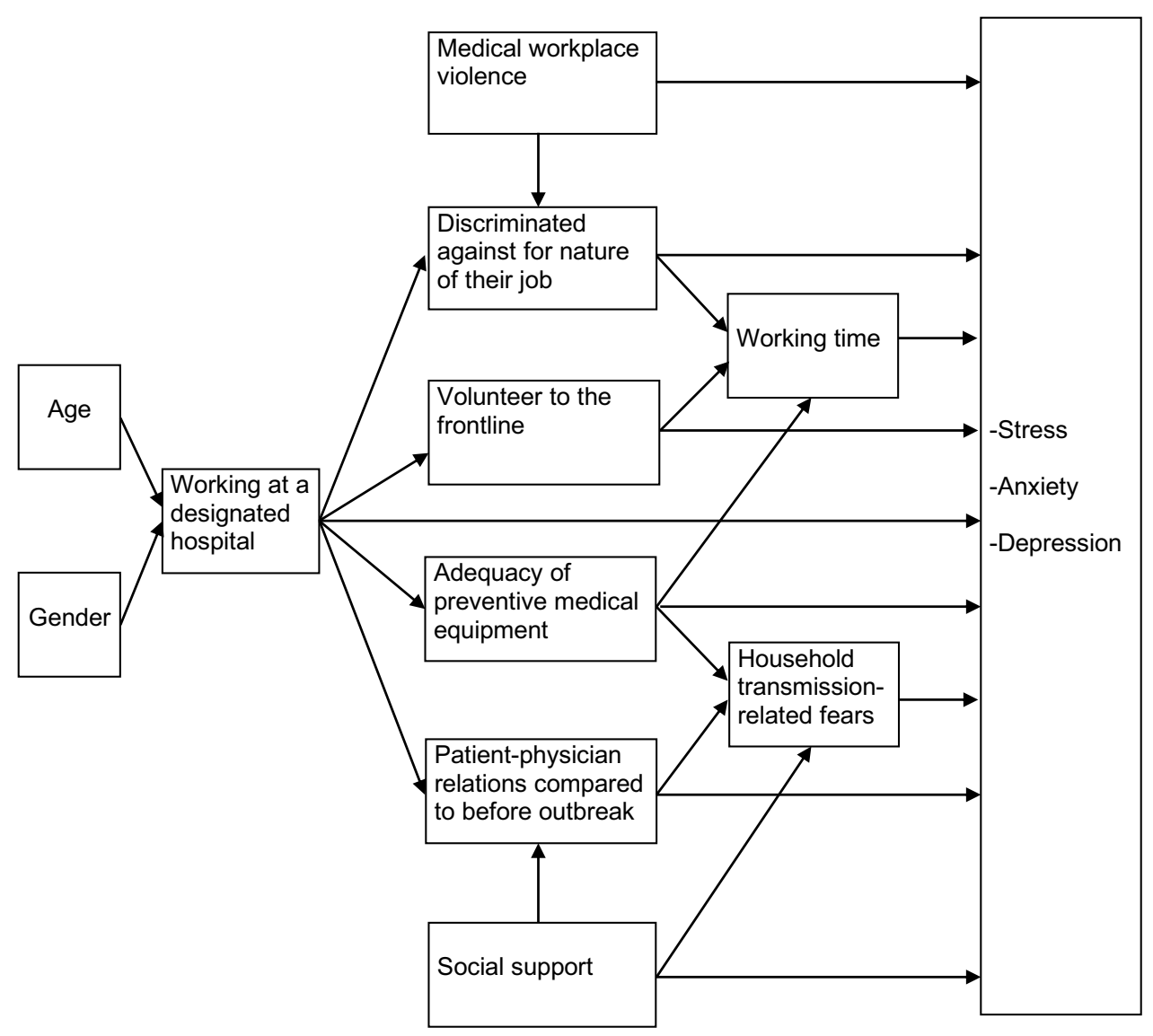

Figure I Effects of independent and intervening variables on stress, anxiety and depression.

\section{References}

1. Yang Y, Lu L, Chen T, et al. Healthcare worker's mental health and their associated predictors during the epidemic peak of COVID-19. Psychol Res Behav Manag. 2021;14:221-231. doi:10.2147/PRBM. S290931

2. Nugroho HSW, Suparji S, Martiningsih W, Suiraoka IP, Acob JRU, Sillehu S. A response to "effect of integrated pictorial handbook education and counseling on improving anemia status, knowledge, food intake, and iron tablet compliance among anemic pregnant women in Indonesia: a quasi-experimental study" [Letter]. $J$ Multidiscip Healthc. 2020;13:141-142. doi:10.2147/JMDH.S247401
3. Susatia B, Martiningsih W, Nugroho HSW. A. Response to "Prevalence and Associated Factors of Musculoskeletal Disorders Among Cleaners Working at Mekelle University, Ethiopia". J Pain Res. 2020;13:2707-2708. doi:10.2147/JPR.S281683

4. Garson GD. Partial Least Squares: Regression and Structural Equation Models. Statistical Associates Publishing: Asheboro; 2016.

Dove Medical Press encourages responsible, free and frank academic debate. The content of the Psychology Research and Behavior Management 'letters to the editor' section does not necessarily represent the views of Dove Medical Press, its officers, agents, employees, related entities or the Psychology Research and Behavior Management editors. While all reasonable steps have been taken to confirm the content of each letter, Dove Medical Press accepts no liability in respect of the content of any letter, nor is it responsible for the content and accuracy of any letter to the editor.

Psychology Research and Behavior Management

Dovepress

\section{Publish your work in this journal}

Psychology Research and Behavior Management is an international, peer-reviewed, open access journal focusing on the science of psychology and its application in behavior management to develop improved outcomes in the clinical, educational, sports and business arenas. Specific topics covered in the journal include: Neuroscience, memory and decision making; Behavior modification and management; Clinical applications; Business and sports performance management; Social and developmental studies; Animal studies. The manuscript management system is completely online and includes a very quick and fair peer-review system, which is all easy to use. Visit http://www. dovepress.com/testimonials.php to read real quotes from published authors. 